\title{
Lymphocyte Subpopulations in Mediastinal Milky Spots of Mice: Light- and Electron-Microscopic Immunohistochemical Observations
}

\author{
Naomi INOUE and Yoshinori OTsukI \\ Department of Anatomy, Osaka Medical College, Takatsuki, Japan \\ Received October 21, 1991
}

\begin{abstract}
Summary. The structure and distribution of cellular components in the mediastinal milky spots of $\mathrm{C} 57 \mathrm{BL} / 6$ mice were studied by electron microscopy and immunohistochemistry. The mediastinal milky spots were generally covered with plump mesothelial cells with hemidesmosome-like structures in small projections of the cytoplasm, and consisted mainly of clusters of lymphocytes, macrophages and fibroblasts. Macrophages and lymphocytes were often seen passing between mesothelial cells and migrating into the pleural cavity. Neither high endothelial venules (HEV) nor lymphatics were present in the mediastinal milky spots. Thy-1(CD5)-, L3/T4(CD4)- and Lyt-2(CD8)-positive cells were located predominantly at the basal area adjacent to fat cells under the lymphoid tissue. IgG- and Ia-positive cells dominated throughout the lymphoid tissue, whereas IgM-positive cells were observed in the lymphoid tissue other than the basal area. Mediastinal milky spots showed a specific distribution of lymphocyte subsets: the $T$ cell area comprised the basal area, and the $B$ cell area was mainly other areas.

The mean percentages of CD4-, CD8-, IgM-, IgG- and IgA-positive cells in the mediastinal milky spots were $16.5 \%, 20.1 \%, 28.8 \%, 37.3 \%$ and $2.1 \%$, respectively; the percentage of $B$ cells was higher than that of $T$ cells. IgG- and IgM-positive cells were the main lymphocyte subsets in the mediastinal milky spots. The most characteristic finding was that $\operatorname{IgA}$-positive cells were a very minor cellular component.
\end{abstract}

Milky spots were first described as white spots in the omentum and in the serous layer of the thoracic cavity of young rabbits by RECKLINGHAUSEN (1863) as "Milchflecke". Since then, many studies have been conducted in several species on the structure and function of milky spots with reference to macrophages in the omentum and mediastinal pleura (MIXTER, 1941;
IMAI et al., 1971; TAKEMORI, 1979a; BEELEN et al., 1980, 1988; CRANSHAW and LEAK, 1990). Moreover, the presence of milky spots has been confirmed not only in the greater omentum and pleura but also in the parietal peritoneum covering the pancreas (TAKEMORI, 1979b) and pericardium (NAKATANI et al., 1988; TAKADA et al., 1991). Most of these studies have focused on the origin and function of macrophages in the milky spots. The immunological role of lymphocytes in milky spots has not been clarified, although it is well known that milky spots contain clusters of macrophages and lymphocytes.

The purpose of this study is this clarification of the ultrastructural characteristics of the milky spots in the mediastinal pleura, using conventional light and electron microscopy, and an immunohistochemical determination of the distribution and percentage of lymphocyte subsets.

\section{MATERIALS AND METHODS}

Twenty-three female specific pathogen-free (SPF) C57BL/6 mice (21-23 g), obtained from the Japan SLC Laboratories, Inc. (Hamamatsu, Japan) were used in this study.

\section{Light and electron microscopy}

Six mice were anesthetized with pentobarbital by intraperitoneal injection and perfused via the left ventricle, first with $50 \mathrm{ml}$ of heparinized saline, then with a fixative solution of $1.25 \%$ glutaraldehyde and $1 \%$ paraformaldehyde in $0.1 \mathrm{M}$ sodium cacodylate buffer at pH 7.4 (Karnovsky's fixative). The fixed mediastinal pleura was removed quickly and immersed in the same fixative for $2 \mathrm{~h}$ at $4^{\circ} \mathrm{C}$, cut into small 
pieces, then post-fixed in $1 \%$ osmium tetroxide in 0.1 $\mathrm{M}$ cacodylate buffer solution for $2 \mathrm{~h}$ at $4^{\circ} \mathrm{C}$. These specimens were dehydrated with a graded series of ethanol, transferred to propylene oxide and embedded in epoxy resin (Epon 812). Semithin sections ( $1 \mu \mathrm{m}$ thick) were stained with toluidine blue for light microscopy. Ultrathin sections ( $60-80 \mathrm{~nm}$ thick) were cut with a MT-2 ultramicrotome, double-stained with uranyl acetate and lead citrate, and observed in a Hitachi H-300 electron microscope.

\section{Immunohistochemistry}

For light immunohistochemistry of stretched membrane specimens, seven mice were anesthetized and perfused, first with $50 \mathrm{ml}$ of heparinized saline, and then with $150 \mathrm{ml}$ of periodate-lysine-paraformaldehyde fixative (PLP solution). Some of the membrane specimens were stained with an indirect immunoperoxidase technique (TAYLOR, 1978). Rat monoclonal antibody against mouse Thy-1 on pan T cells (CD5), L3/ $\mathrm{T} 4$ on helper/inducer T cells (CD4), Lyt-2 on suppressor/cytotoxic T cells (CD8) and Ia (all from SeraLab, Sussex, England), and goat antisera against mouse IgG, IgM and IgA (all from Sigma, St. Louis, MO U. S. A.) were used in dilutions of $1: 500$ with $0.01 \%$ phosphate-buffered saline (PBS) containing $1 \%$ normal rabbit serum (NRS) (DAKO, Glostrup, Denmark). Peroxidase activity was revealed by diaminobenzidine tetrahydroxychloride (DAB). The tissues were counterstained with $1 \%$ methyl green and coverslipped.

In six mice, the mediastinal pleura-following fixation with PLP solution-was transferred to $0.1 \mathrm{M}$ phosphate buffer (PB) $(\mathrm{pH} 7.4)$ containing $5 \%$ sucrose for $12-18 \mathrm{~h}, 10 \%$ sucrose for $1 \mathrm{~h}$, and $20 \%$ sucrose for $3 \mathrm{~h}$ at $4^{\circ} \mathrm{C}$. The tissues were rapidly frozen in ethanol with dry ice and mounted with Tissu Mount (Chiba Medical Inc., Saitama, Japan). The frozen blocks were cut serially into $6 \mu \mathrm{m}$ thick sections with a cryotome (Microm, Heidelberg, Germany) at $-30^{\circ} \mathrm{C}$. Serial cryo-sections were prepared on gelatin-coated glass slides. Some of these serial cryo-sections were stained with hematoxylin and eosin at intervals of 30 sections for confirmation of the presence of milky spots. Serial cryo-sections were immunostained on glass slides by the indirect immunoperoxidase technique, as described above, and were counterstained with $1 \%$ methyl green. Antibody-positive cells were examined in the serial cryo-sections vertical to the surface of the milky spots and counted to determine percentages (mean \pm standard deviation).

For immuno-electron microscopy, the remaining four mice were anesthetized and fixed with $150 \mathrm{ml}$ of $4 \%$ paraformaldehyde, $0.05 \%$ glutaraldehyde, $0.2 \%$ picric acid in $0.1 \mathrm{M} \mathrm{PB}(\mathrm{pH}$ 7.4). Then the specimens were stained by the indirect immunoperoxidase technique, as described above for cryo-sections. After post-fixation with $1 \%$ osmium tetroxide in $0.1 \mathrm{M} \mathrm{PB}$ (pH 7.4) for $1 \mathrm{~h}$, they were embedded in Epon 812 and stained with $1 \%$ uranyl acetate in $70 \%$ ethanol. Ultrathin sections ( $60-80 \mathrm{~nm}$ thick) were examined in a Hitachi H-300 electron microscope.

\section{RESULTS}

\section{Light and electron microscopic observations}

Epoxy resin sections ( $1 \mu \mathrm{m}$ thick) stained with toluidine blue revealed that mice milky spots-generally lacking a germinal center-were covered with mesothelial cells and consisted of a cluster of macrophages, lymphocytes and fibroblasts and abundant blood capillaries (Fig. 1). The mesothelial cells which covered the surfaces of the lymphoid tissue were plump and uneven in shape, in contrast to the slender mesothelial cells in other parts of the serous membrane. Moderate numbers of lymphocytes and macrophages were often observed between the mesothelial cells.

Electron microscopy showed that the surfacecovering mesothelial cells possessed a large, round nucleus and contained many mitochondria, cisterns of rough endoplasmic reticulum and free ribosomes as well as moderately developed Golgi complexes and a few lysosomes in the cytoplasm. The surface of the mesothelial cells was generally smooth, but the cytoplasm extended a few short microvilli toward the pleural cavity and small projections into the connective tissue toward the basal surface. The most characteristic finding was that the projections possessed scattered spots of hemidesmosome-like structures (Fig. 2a). The basal lamina was poorly developed and discontinuous. The lining of mesothelial cells was often interrupted by macrophages and lymphocytes passing through the gaps $(1-3 \mu \mathrm{m}$ in diameter) between mesothelial cells (Fig. 2b). Macrophages contained many lysosomes and vacuoles, moderate numbers of rough endoplasmic reticulum cisterns and a few mitochondria. Their nucleus was more irregular in shape and smaller in size than that of mesothelial cells. Moreover, the projections of macrophages showed no junctional apparatuses such as hemidesmosome-like structures in mesothelial cells. Milky spots consisted of many lymphocytes, moderate numbers of macrophages and fibroblasts as well as a few plasma cells located in the lateral area adjacent to fat cells. Interdigitating cells and Langerhans cells 


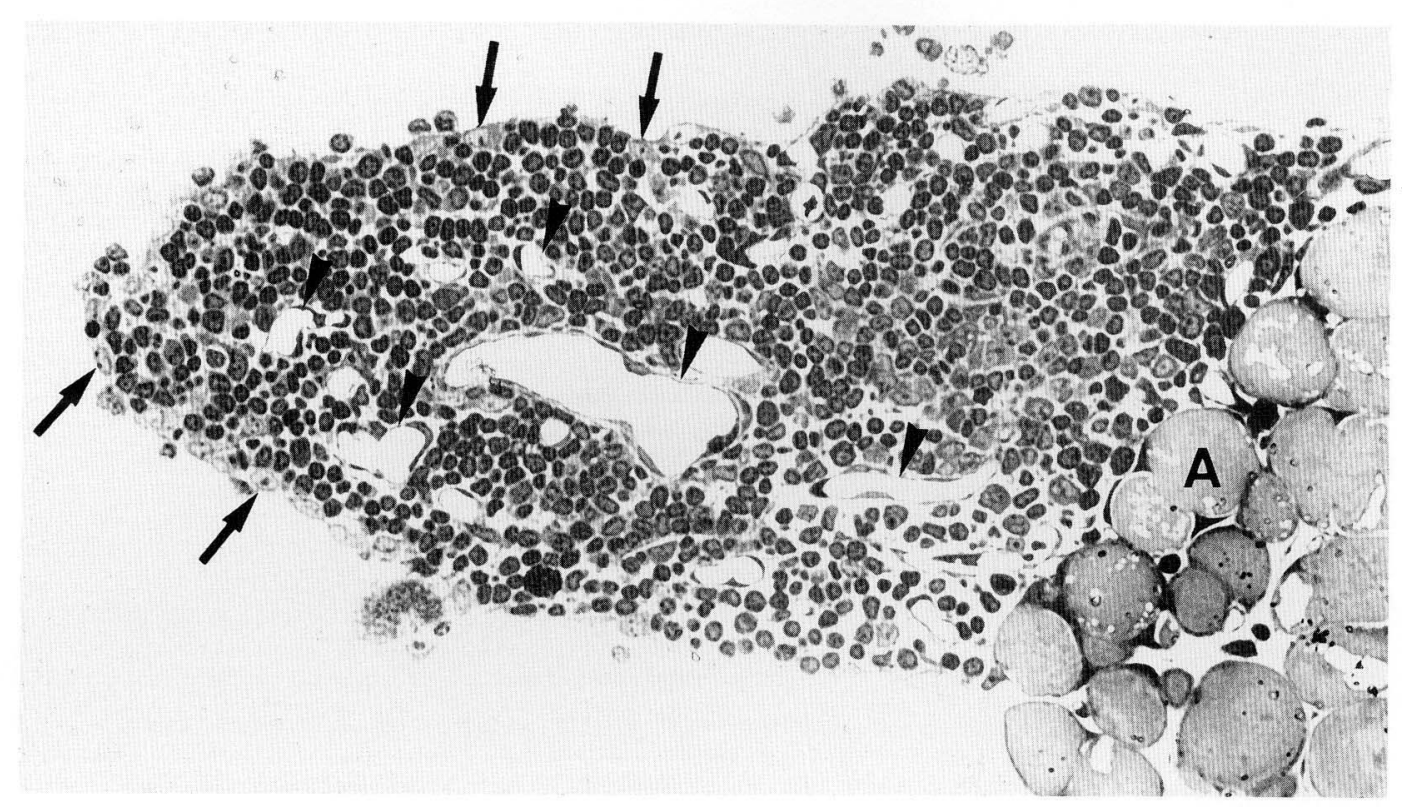

Fig. 1. Epoxy resin section of a mouse milky spot (1 $\mu \mathrm{m}$ thick) stained with toluidine blue. The milky spot is covered with mesothelial cells (arrows) and consists of many lymphocytes and moderate numbers of macrophages, and contains blood capillaries (arrowheads). $A$ adipose cells. $\times 350$

were not seen in the lymphoid tissues. Blood capillaries, observed throughout the lymphoid tissue, often had fenestrated endothelial cells, whereas high endothelial venules (HEV) or lymphatic capillaries could not be found in the lymphoid tissues.

\section{Immunohistochemical observation}

\section{Membrane specimens}

Moderate numbers of T cell subsets (CD5-, CD4- and CD8-positive cells), many IgG- and IgM-positive cells and only a few IgA-positive cells were seen in the mediastinal lymphoid tissues. They showed no specific distribution patterns and were diffused throughout the lymphoid tissue (Fig. 3).

\section{Cryo-sections and ultra-thin sections}

In cryo-sections, individual immunoreactive cells were easily identified; the percentages of the cells in the milky spots are listed in Table 1 .

CD5-positive cells were not very numerous in the milky spots $(29.3 \pm 2.9 \%)$. They were located at the basal area adjacent to fat cells under the lymphoid tissue, and were sparse in the center of the lymphoid tissue and beneath the mesothelial cells (Fig. 4a). The distribution of CD4- and CD8-positive cells was simi- lar to that of CD5-positive cells (Fig. 4b). The mean percentage of CD4-positive cells was similar to that of CD8-positive cells $(16.5 \pm 1.9 \%$ and $20.1 \pm 1.9 \%$, respectively).

Many IgG-positive cells, $37.3 \pm 2.6 \%$, were present throughout the lymphoid tissues as were IgM-positive cells, $28.8 \pm 2.4 \%$, except for the basal area (Fig. 4c). Only a few IgA-positive cells, $2.1 \pm 0.1 \%$, were seen (Fig. 4d).

Ia-positive cells were most numerous in the milky spots $(47.9 \pm 1.9 \%)$. Many Ia-positive cells were present throughout the lymphoid tissues, and their distribution was similar to that of IgG-positive cells.

Immuno-electron micrographs revealed that a few CD5-, CD4- and CD8-positive cells were present beneath the mesothelial cells, and CD4-positive cells often came in contact with macrophages both in the superficial layer adjacent to the mesothelial cells and in the basal area of the lymphoid tissue. The Ia antibody was observed on the cell surface of some lymphocytes, macrophages and mesothelial cells as DAB reaction products. IgG- and IgM-positive cells and Ia antibody-positive macrophages often appeared passing between mesothelial cells (Fig. 5), as did CD4-, CD5- and CD8-positive cells. 


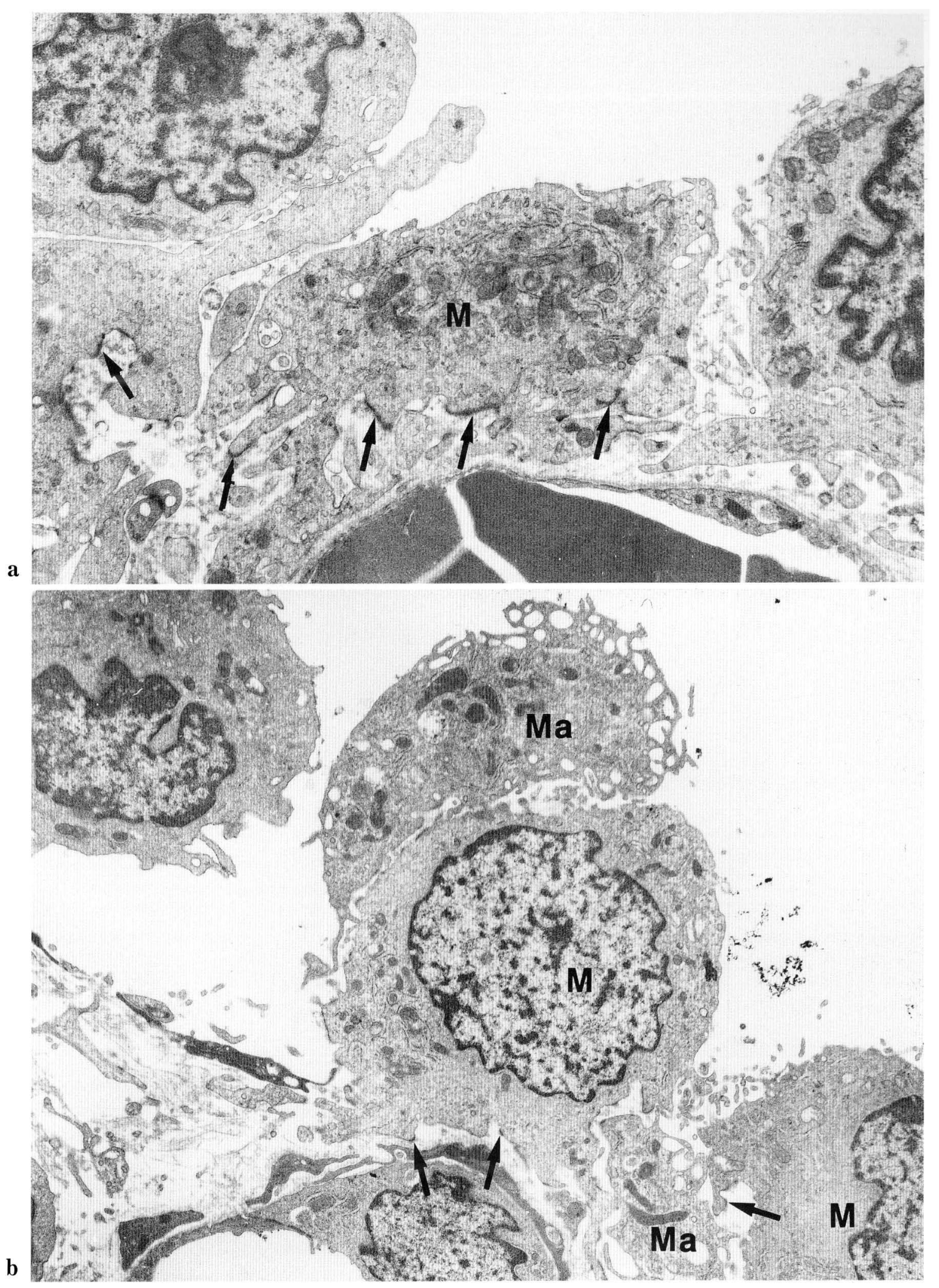

Fig. 2 a. Surface-covering mesothelial cells $(M)$ are plump and possess hemidesmosome-like structures (arrows). $\times 12,000$. b. A macrophage $(M a)$ passing between mesothelial cells $(M)$. Note the hemidesmosomelike structures of the mesothelial cells (arrows). $\times 9,200$ 
Fig. 3. Light micrograph of CD5positive cells in a stretched membrane specimen of a mouse mediastinal milky spot. Many CD5-positive cells are diffused in the lymphoid tissue (arrows). $\times 520$

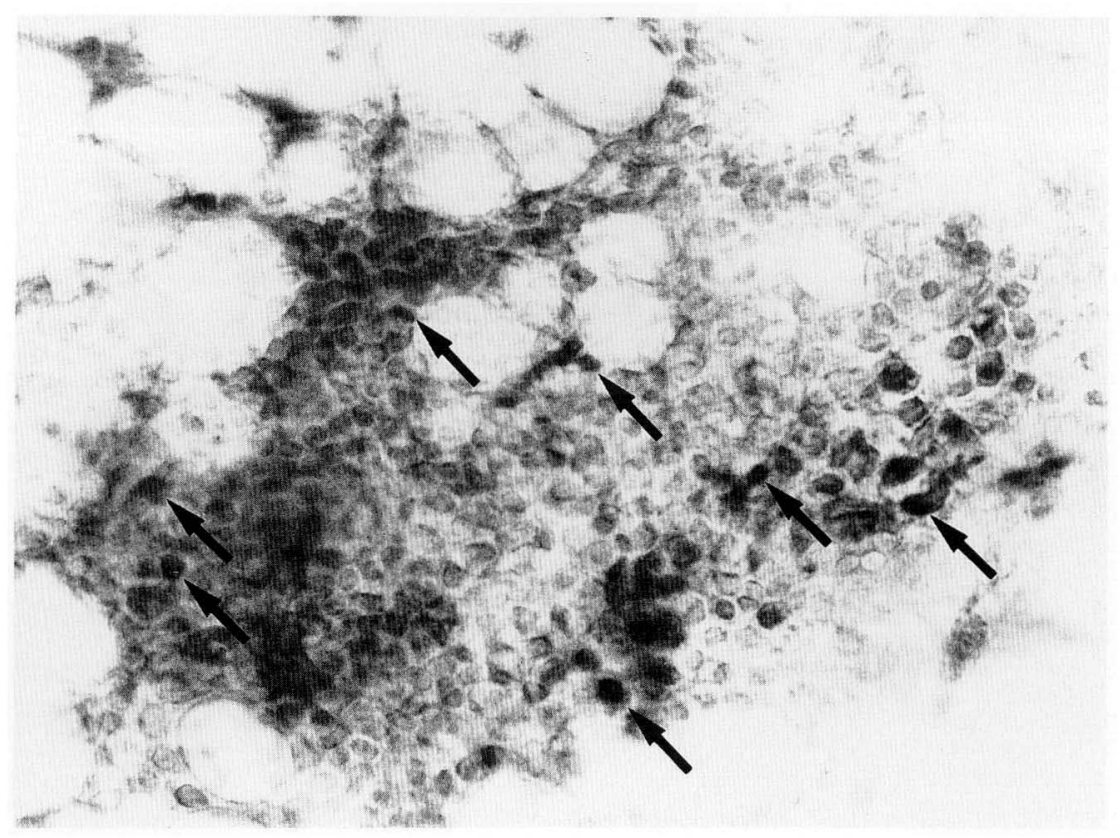

Table 1. Percentages of cells (mean \pm standard deviation) labeled with various antibodies in the mediastinal milky spots of mice

\begin{tabular}{lc}
\hline Antibodies & $\begin{array}{c}\text { Percentage of antibody- } \\
\text { positive cells }\end{array}$ \\
\hline CD5 & $29.3 \pm 2.85$ \\
CD4 & $16.5 \pm 1.89$ \\
CD8 & $20.1 \pm 1.92$ \\
Ia & $47.9 \pm 1.86$ \\
IgM & $28.8 \pm 2.42$ \\
IgG & $37.3 \pm 2.61$ \\
IgA & $2.1 \pm 0.12$ \\
\hline
\end{tabular}

\section{DISCUSSION}

There have been few studies on the cellular components of mediastinal milky spots, in contrast to omental milky spots. In previous immunohistochemical studies of omental milky spots, the following two methods were applied: membranous specimens in situ (Shimotsuma et al., 1991) and cryo-sections (Dux et al., 1986). Shimotsuma et al. (1991) reported that lymphocytes and macrophages in human omental milky spots did not show any preferential pattern of distribution. On the other hand, Dux et al. (1986) described $\mathrm{T}$ cells as located centrally and $\mathrm{B}$ cells peripherally in the omental milky spots in mice. In this study, we matched SHimotsuma et al. in being unable to determine the exact distribution of lymphocyte subsets using membrane specimens of mouse mediastinal pleura, owing to the thickness of the membrane specimens $(100-200 \mu \mathrm{m})$ and overlapping of the cells. However, our cryo-sections, stained with indirect immunoperoxidase technique, confirmed the definite distribution of lymphocyte subsets in mediastinal milky spots.

Moderate numbers of CD5-, CD4- and CD8-positive cells were present at the basal area of the lymphoid tissue, in contrast to the IgM-positive cells located throughout the lymphoid tissue but not at the basal area. The distribution of lymphocyte subsets (central area for B cells and peripheral area for $\mathrm{T}$ cells in mediastinal milky spots) was clearly the reverse of the data given by Dux et al. (1986).

The distribution of lymphocyte subsets in various lymphoid tissues has been attracting increased interest ever since the concept of mucosa-associated lymphoid tissue (MALT) was proposed by BIENENSTOCK and BEFUs (1980). Both mediastinal milky spots, as studied here, and MALT have T cell and B cell areas. Gut-associated lymphoid tissues (GALT) and 

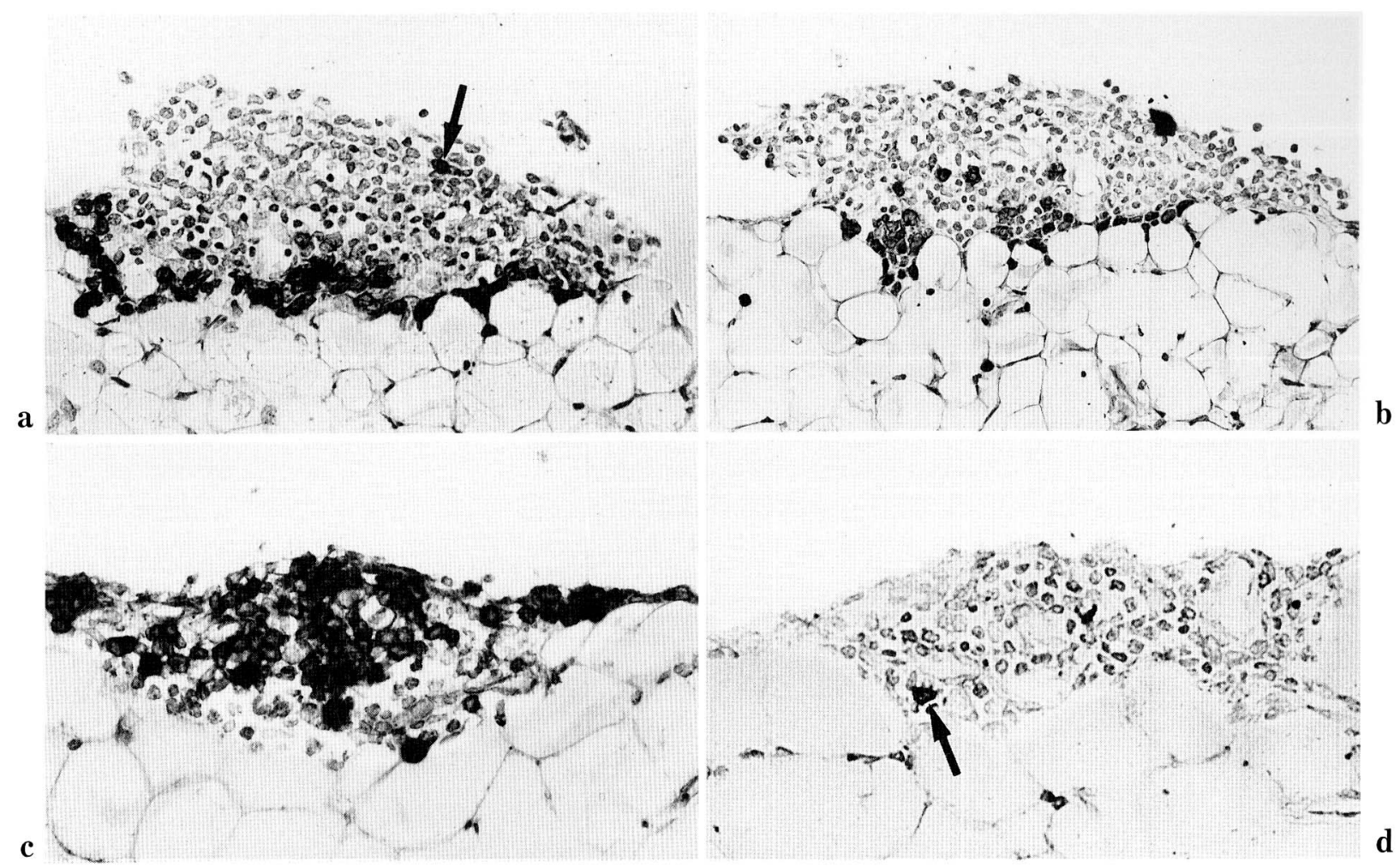

Fig. 4. Light micrographs combined with immunohistochemistry showing CD5-, CD4-, IgM- and IgA-positive cells in a mouse milky spot. a. CD5-positive cells are distributed mainly in the basal area of the lymphoid tissue and sparsely throughout lymphoid tissue (arrow). $\times 250$. b. The distribution of CD4-positive cells is similar to that of CD5-positive cells. $\times 210$. c. The distribution of IgM-positive cells is similar to that of IgG-positive cells except for a lack of positive cells in the basal area. $\times 310$. d. Only a few IgA-positive cells (arrow), in contrast to many IgG- and IgM-positive cells, are seen in the mouse milky spots. $\times 310$

bronchus-associated lymphoid tissues (BALT) are always exposed to the exogenous antigens through the epithelium, and the structure of these tissues are in some respects similar to that of lymph nodes: the presence of a germinal center, HEV in the T cell area and lymphatic capillaries around the lymphoid tissues (SMinia and Plesch, 1982; BreEl et al., 1988; OTSUKI et al., 1988, 1989a). On the other hand, mediastinal milky spots as well as fallopian tube- (OTSUKI et al., 1989b) and uterus-associated lymphoid tissues (OTSUKI et al., 1990) are normally under aseptic conditions and possess common structures such as the absence of a germinal center, HEV and lymphatic capillaries, the presence of only a few plasma cells and many lymphocytes and macrophages migrating between epithelial cells. These findings suggest lymphoid tissues divide into two groups according to the presence or absence of exposure to exogenous antigens, and their structures reflect the organ-specific immunological conditions.

Percentages of T lymphocytes (CD3) and B lymphocytes (CD19) have been reported by Shimotsuma et al. (1991) as $11.7 \%$ and $29.1 \%$. The data by Dux et al. (1986) showed that pan T cells and IgG-positive cells were $20.0 \pm 5 \%$ and $41.5 \pm 1 \%$, respectively. Our results of cryo-sections are in agreement with these two studies; the percentage of B cells was higher than that of $\mathrm{T}$ cells. The percentage of lymphocyte subsets was characteristic in MALT. The major lymphocyte subsets were IgG- and IgM-positive cells in mouse mediastinal milky spots, T cells, IgA- and IgM-positive cells in rat GALT (OTsuki et al., 1988), pan T cells in rat BALT (OTSUKI et al., 1989a), and suppressor $\mathrm{T}$ cells in human fallopian tube- and uterus-associated lymphoid tissues (MORRIs et al., 1986; OTSUKI et al., 1989b; OTsUKI et al., 1990). It remains to be determined if the variety of major lymphocyte subsets among these lymphoid tissues is caused 


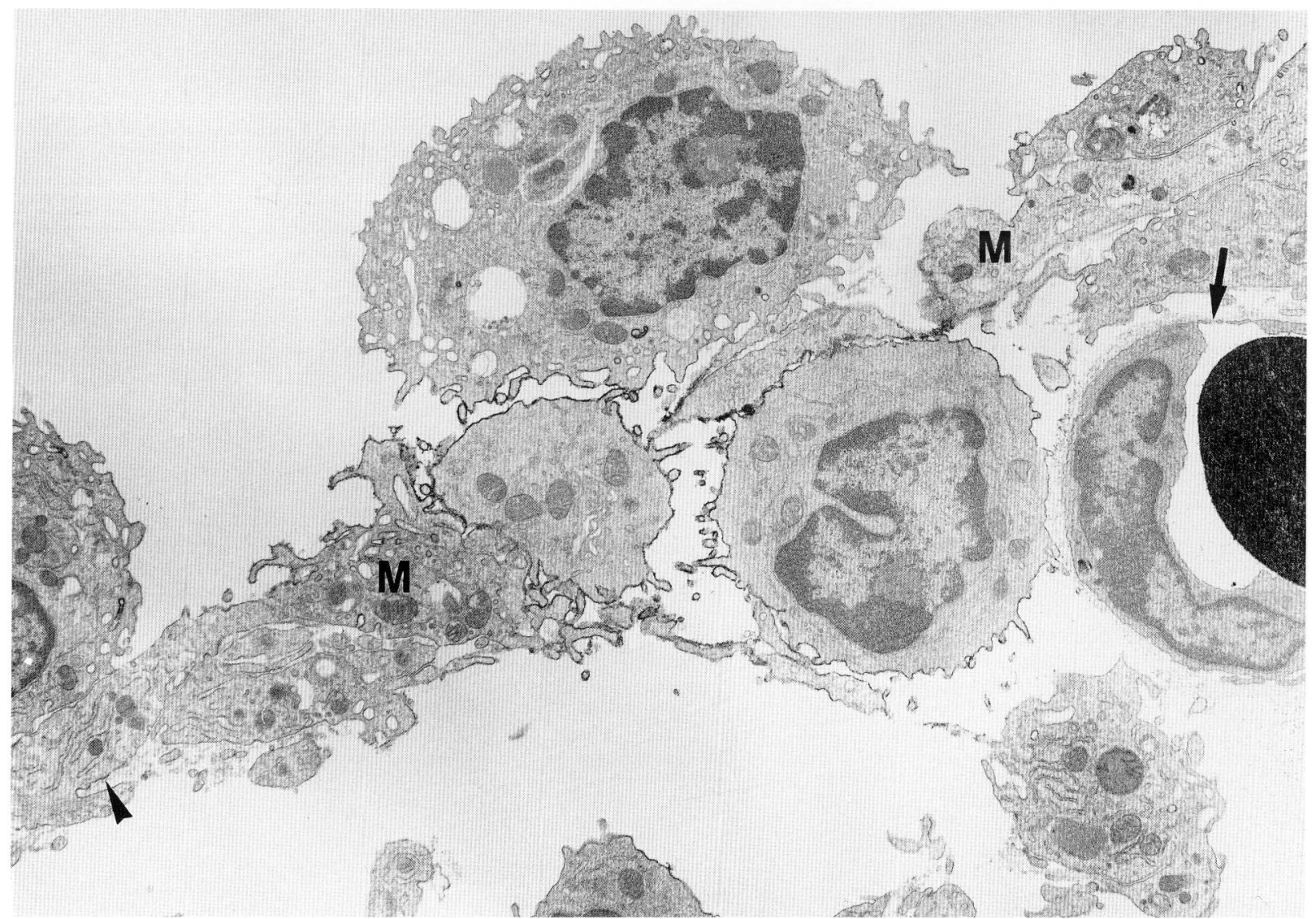

Fig. 5. Electron micrograph showing some IgG-positive cells which are passing between mesothelial cells $(M)$. A blood capillary beneath the mesothelial cells shows a fenestrated endothelium (arrow). Note the presence of a discontinuous basal lamina and hemidesmosome-like structure (arrowhead) of a mesothelial cell. $\times 8,300$

by different exogenous antigens coming to the surface of the lymphoid tissues, or by organ-specificity or species difference.

The migratory route of lymphocytes and macrophages has not yet been clarified in mediastinal milky spots. These recirculating cells are considered to pass between mesothelial cells into the pleural cavity, then enter lymphatic capillaries via macula cribriformlike structures which are located in the intercostal spaces (NAKAI, 1963). However, further studies are needed to delineate the afferent migratory route of lymphocytes and macrophages into the mediastinal milky spots, because mediastinal milky spots possess no HEV or lymphatic capillaries as did the migratory route observed in GALT (OTSUKI et al., 1988) and BALT (OTsUkI et al., 1989a). It is also rare to encoun- ter monocytes and lymphocytes passing through the blood capillaries within the lymphoid tissues.

The determination of whether or not macrophages in the mediastinal milky spots are derived from monocytes or mesothelial cells remains (IMAI et al., 1987; BEELEN et al., 1988). It is possible to distinguish macrophages from mesothelial cells by their ultrastructures but not by Ia-antibody immunostaining. The most conspicuous difference in their ultrastructure is the presence of hemidesmosome-like structures in mesothelial cells but not in macrophages. On the other hand, macrophages and some mesothelial cells are often labeled with Ia-antibody. This finding suggests the possibility that mesothelial cells as well as macrophages are antigen-presenting cells. 


\section{REFERENCES}

Beelen, R. H. J., D. M. Fluitsma and E. C. M. HoefsMIT: The cellular composition of omentum milky spots and the ultrastructure of milky spot macrophages and reticulum cells. J. Reticuloendothel. Soc. 28: 585-599 (1980)

Beelen, R. H. J., I. L. Eestermans, E. A. DöpP and C. D. DiJKstra: Immunological characteristics of milky spots in the omentum of rats. Adv. Exp. Med. Biol. 237: 745-750 (1988).

Bienenstock, J. and A. D. Befus: Mucosal immunology. Immunology 41: 249-270 (1980).

Breel, M., M. Van der Ende, T. Sminia and G. Kraal: Subpopulations of lymphoid and non-lymphoid cells in bronchus-associated lymphoid tissue (BALT) of the mouse. Immunology 63: 657-662 (1988).

Cranshaw, M. L. and L. V. LeaK : Milky spots of the omentum: A source of peritoneal cells in the normal and stimulated animal. Arch. Histol. Cytol. 53, Suppl.: 165-177 (1990).

Dux, K., R. V. Rouse and B. Kyewski: Composition of the lymphoid cell populations from omental milky spots during the immune response in $\mathrm{C} 57 \mathrm{BL} / \mathrm{Ka}$ mice. Eur. J. Immunol. 16: 1029-1032 (1986).

Imai, Y., T. KaSajima and M. Matsuda: Electron microscopic study on the peritoneal macrophage and milky spot in omentum. Rec. RES Res. 11: 54-84 (1971).

Imai, Y., M. Yamakawa, K. Maeda, A. Matsuda and T. SATo : Omental milky spot and peritoneal macrophage - Characteristics, function and ontogeny. J. Jap. Soc. Clin. Cytol. 26: 572-580 (1987).

MixTER, R. L.: On macrophagal foci ("milky spots") in the pleura of different mammals, including man. Amer. J. Anat. 69: 159-186 (1941).

Morris, H., M. Emms, T. Visser and A. Timme: Lymphoid tissue of the normal fallopian tube $-\mathrm{A}$ form of mucosal-associated lymphoid tissue (MALT)? Int. J. Gynecol. Pathol. 5: 11-22 (1986).

NAKaI, I.: Experimental studies on the spread of the Ehrlich ascites tumor implanted into the pleural cavity of rat. J. Osaka Med. Coll. 22: 100-120 (1963).

Nakatani, T., H. Shinohara, Y. Fukuo, S. Morisawa and T. Matsuda: Pericardium of rodents: Pores connect the pericardial and pleural cavities. Anat. Rec. 220: 132-137 (1988).

OTSUKI, Y. and S. MagaRi: Lymphocyte subpopulations in high endothelial venules and lymphatic capillaries in rat Peyer's patches: An immunoelectron microscopic study. Acta Histochem. Cytochem. 21: 33-44 (1988).

Otsuki, Y., Y. Ito and S. MaGaRi: Lymphocyte subpopulations in high endothelial venules and lymphatic capillaries of bronchus-associated lymphoid tissue (BALT) in the rat. Amer. J. Anat. 184: 139-146 (1989a).
Otsuki, Y., Y. Maeda, S. Magari and O. Sugimoto: Lymphatics and lymphoid tissue of the fallopian tube: immunoelectronmicroscopic study. Anat. Rec. 225: 288296 (1989b).

Otsuki, Y., Y. Maeda, S. Magari., H. Kubo and 0. Sugimoto: Lymphatics, intraepithelial lymphocytes and endometrial lymphoid tissues in the rabbit uterus: An electron microscopic and immunohistological study. Lymphology 23: 124-134 (1990).

Plesch, B. E. C.: Histology and immunohistochemistry of bronchus associated lymphoid tissue (BALT) in the rat. Adv. Exp. Med. Biol. 149: 491-497 (1982).

Recklinghausen, F. von: Über Eiter- und Bindegewebskörperchen. Virchows Arch. Pathol. Anat. 28: 157-197 (1863).

Shimotsuma, M., T. Takahashi, M. Kawata and K. Dux: Cellular subsets of the milky spots in the human greater omentum. Cell Tiss. Res. 264: 599-601 (1991).

Sminia, T. and B. E. C. Plesch: An immunohistochemical study of cells with surface and cytoplasmic immunoglobulins in situ in Peyer's patches and lamina propria of rat small intestine. Virchows Arch. B. 40: 181-189 (1982).

TAKada, K., Y. OTsuki and S. Magari: Lymphatics and pre-lymphatics of the rabbit pericardium and epicardium with special emphasis on particulate absorption and milky spot-like structures. Lymphology 24: 116-124 (1991).

Takemori, N.: Morphological studies of the omental milk spots in the mouse: Light and electron microscopy. Hokkaido J. Med. Sci. 54: 265-283 (1979a).

- : Milk spots on the parietal peritoneum over the pancreas in the mouse. Hokkaido J. Med. Sci. 54: 379385 (1979b).

TAYLOR, C. R.: Immunoperoxidase techniques: Practical and theoretical aspects. Arch. Pathol. Lab. Med. 102: 113-121 (1978).

\author{
Dr. Naomi Inoue \\ Department of Anatomy \\ Osaka Medical College \\ 2-7 Daigakumachi \\ Takatsuki, Osaka, 569 Japan \\ 井上直已 \\ 569 高柣市大学町 2-7 \\ 大阪医科大学 \\ 解剖学第一講座
}

